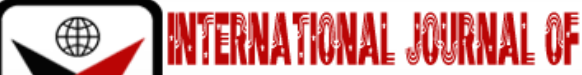

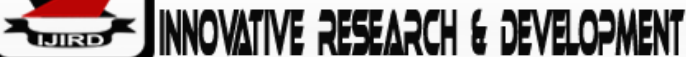

ISSN 2278 - 0211 (Online)

\section{Application of Guidance and Counseling Services to Manage Secondary School Students' Discipline in Monduli District, Tanzania}

\begin{tabular}{c} 
Kanael Paul Abraham \\
Master Degree Candidate, Department of Education, \\
Mwenge Catholic University, Tanzania \\
Muteti Catherine Mueni \\
Oecturer, Department of Education, Mwenge Catholic University, Tanzania \\
Ogoti Evans Okendo \\
Senior Lecturer, Department of Education, Mwenge Catholic University, Tanzania \\
\hline
\end{tabular}

\begin{abstract}
:
The study with a quantitative approach aims to evaluate the application of guidance and counseling services on secondary schools' students' from Monduli District, Tanzania. The target population consists of the District Education Officer, twelve heads of schools, four hundred and six teachers and nine thousand five hundred sixty-fivestudents. Therefore, the study sample consisted of 1 District Education Officer, 6 heads of schools, 6 guidance and counseling teachers and 336 students making a total number of 349 respondents. The study employed questionnaire and interview schedule to collect data from the participants. The collected data were then analyzed descriptively and inferentially. This study clearly revealed that guidance and counseling services have positive impact on students learning for Monduli District.
\end{abstract}

Keywords: Guidance, counseling, discipline, behavior, effectiveness, managing, students disciplinary, counselor

\section{Introduction}

Two most important elements are guidance and counseling those is required by all discipline of students for guiding their behavioral patterns. Without proper discipline, the society can't perform (Kiragu, 2014). Proper guidance and counseling are very important for people to work harmoniously. Researchers have focused on the steady maturity of students (Agenda \&Simatwa, 2017). Students have been viewed as a priceless asset. As per Meyer (1991), discipline problems are the major cause of concern in most of the schools and institutions. For Rue \&Byarr (1992), school discipline in the United States has not change mainly. Guidance and counseling services come to abolish the use of corporal punishments in schools which had been criticized by different education stakeholders as most of them consider it not to be an effective means of maintaining students' discipline in schools. For instance, in Nigeria, Onah et al (2016) reported on teachers' application of punitive forms of punishment such as corporal punishment which is not an effective means of maintaining students' discipline. Similarly, in Ethiopia, Girma (2016) found the use of corporal punishment to be the most common method of handling students' discipline in schools.

In Tanzania, students' discipline has been over time an issue of concern for educators, policy makers and public opinion in general, owing to the outbreak of aggressiveness among peers, violence within teacher and student relationship and vandalism as well, leading to perpetual existence of problem of drop out, deviant behaviours, lateness and poor academic performance among students (Kambuga, Patrick \&Mbalamula, 2018).Good discipline is considered to be one of the major attributes of effective schools and many failing secondary schools have been blamed for lack of discipline (Musa \& Martha, 2020).

Provision of punishment and guidance and counselling services were management strategies of students' indiscipline cases in public secondary schools. Ngalya (2017) argues that management of the issue of indiscipline has become a nightmare for school administrators and teachers in view of the increasing cases of this threat, its effect in effective management of schools as well as the ultimate effect on the society that is why there is a need for each school to have a functioning disciplinary committee that sees to every case of acts of indiscipline of the students. Provision of guidance and counselling services inMonduli District secondary schools had been considered as the best method of handling students' discipline (Mapfumo\&Nkoma, 2013). The application of guidance and counseling services can help the students to understand themselves as well as understanding others and hence improve their relationship (Karcher, 2004). Though guidance and counseling services are provided in secondary schools in Tanzania, little is known how such practices contribute to the management of students' discipline. This is the motivation behind this study. 


\section{Statement of the Problem}

Indiscipline among students in public secondary schools has been an issue of concern among education stakeholders. Teachers and other education stakeholders have been blamed heads of schools for not effectively apply guidance and counseling services at school for managing students' discipline. Despite the government of Tanzania's efforts to enforce discipline in secondary schools, indiscipline cases such as truancy, drug abuse, early sexual engagement, disrespect and dropout have continued in secondary schools with a new dimension which are violent, destructive and caused maximum harm to human life (URT, 2016). There seems to be lack of effective alternative strategies by heads of schools to maintain students' indiscipline. Various studies like Agenda \&Simatwa (2017); Agenda \&Simatwa (2011); Ngalya, (2017) focuses on management of student discipline in secondary school.

\section{Research Question}

i. What are the opinions of Monduli District based secondary schools' students regarding the guidance and counseling services?

\section{Research Hypothesis}

i. Teachers' and students' mean perception changes regarding the effectiveness of guidance and counseling services towards managing the Monduli District based students'.

\section{Significance of the Study}

The findings of this study provide awareness to Ministry of Education Science and Technology (MOEST) on the application of guidance and counseling service in management of students' discipline aims to assist the policy makers to develop policies that emphasize the application of guidance and counseling services to manage students' discipline.

\section{Theoretical Framework}

This study was guided by Behavioral Theory. The theory was developed by John Hopkins, (1878 -1958) an influential American Psychologists whose most famous work occurred during the early $20^{\text {th }}$ Century at Johns Hopkins University. The theory is based on the assumption that behavior can be learned, unlearned and re-learned. The view is that learning and its process on the environment critically affect the way people think and act. The behavioral theory is grounded on a scientific point of view of human behavior that applies a systematic and structured approach to counseling. Behavior modification or behavioral therapy is the application of basic research and theory from experimental psychology to influence behavior for purposes of resolving personal and social problems and enhancing human functioning. The hallmark of behavior therapy is the identification of specific goals at the one set of counseling process. Usually, the goals are very specific, that is to change a single or small range of behaviors. A key concept of behaviorism comprises the stimulus - response equation, the classical and operant conditioning the reinforcement and punishment notions.

In helping clients to achieve their goals, behavior counselors usually assume an active and directive role. Although the client generally determines what behavior would be changed, the counselor usually determines on how this behavior can best be modified. A counselor can best teach self-discipline, risk taking, openness and honesty among others to students. Assertion training that helps people to express their feelings, thoughts, beliefs and attitudes are also emphasized in behavioral approach. Through students were able to deal with interpersonal difficulties as they stay in schools. Behavior theory seeks to enhance behavior modification among the clients and if effectively applied to students, it helps in their life. Through behavioral theory, can help in establishing and implementing provision of school guidance and counseling services, and resolving student's discipline problems in secondary schools in Monduli District would be attained.

Strength of behavioral theory is on observable behaviors which ease quantification and collection of data during conducting research which provides clear explanations and evidences on a certain phenomenon. Behavior intervention, analysis and discrete trial training come from behaviorism which is important in changing harmful behaviors in children and adults. Punishment and rewards facilitate learning. In conclusion, behavior theory aid learning things when it applied properly to students.

The weakness of behavior theory is that it does not account other learning types particularly that occur without punishment and reinforcement. Most human behavior and learning abilities are attributed to effects of external factors such as reinforces or punishers. "Not everything can be explained by external influence, there are other ways. People are able to adapt their behavior when new information is introduced. Regardless of what behavior an individual learned in the past through the reinforcement system, he or she can still modify or change when new circumstances offer new information.

This theory considers only what is observable and measurable though there are unseen aspect of individual which are vital in his or her personalities and the way one relates to the surrounding environment. It ignores the importance of cognitive psychological processes, which focuses on internal process such as moods, thoughts and feelings, perception and learning from reflection, which have a major part to play in facilitating an understanding learning. A part from its weakness, this theory is important to schools as they strive to provide guidance and counseling services to students for the purpose of improving their discipline.

\section{Empirical Literature Review}

Hughes, Law and Meijers (2017) conducted study to understand that guidance and counseling is not meant for people with HIV/AIDS alone rather for all people including students in secondary schools. A study in Ireland by Leahy, Flaherty and Herne, (2017) found that teacher counselors teaching workload and quality of counseling services; it reveals 
that teacher counselors handled the normal workload (More than 18 lessons) per week and also handled less school guidance and counseling sessions. Kiptala\&Kipruto (2021) conducted study to investigate Students' Perception of the Influence of Guidance and Counselling Services and Academic Performance in Baringo County, Kenya. Also was noted that there was less training among school counselors in the studied secondary schools. It was also though some school counselors attended some trainings, their knowledge, skills and awareness to school counseling principles was very limited. The finding indicated that guiding and counseling services was provided in schools though most of school counselors had no enough training. The study showed that school counselors' perception was good but the study didn't involve students because are the ones which are directly affected by guidance and counseling services at school, therefore the current study was conducted to investigate the application of guidance and counseling services in managing student's discipline in secondary schools in Monduli District, Tanzania.

The study by Sima, (2018) examined the challenges in the provision of counseling services in Secondary schools in Tanzania where it was revealed that teacher counselors were mainly challenged by the unavailability of counseling facilities, including confidential rooms for conducting interviews. They had a high workload that limits their performance as counselors to attain the effectiveness. At the same time some counselors were somewhat incompetent and in some cases Heads of Schools violated Ministry directive in selecting school counselors. This study has shown challenges that affect effectiveness of guidance and counseling in secondary school, Tanzania. Malisa, (2017) revealed despite the importance of guidance and counseling in schools, the guidance and counseling procedures in Secondary schools were not effective thus affected student's behavior.

The reviewed empirical studies show that guidance and counseling services can be a good way of improving students' behavior and therefore enhancing academic achievements (Kiptala\&Kipruto, 2021). Also, literature show that through guidance and counseling, students can be prevented from engaging in bad conducts within and outside the school and thus making them to concentrate on academic issues (Enkech et al., 2016). The reviewed literature also has suggested the need of teacher counselors to be equipped with skills and knowledge for them to offer guidance and counseling services (Leahy et al., 2017). However, some studies shows that schools do not have specifically trained counselors and some of them have negative views on guidance and counseling services (Nkuba\&Kyaruzi, 2015; Egbo, 2015). This raises a concern on whether the application of guidance and counseling services is effective towards maintaining students' discipline in schools. Additionally, there is limited literate on the application of guidance and counseling services to manage discipline in public secondary schools. To fill this gap therefore, the current study was conducted to assess the application of guidance and counseling services towards managing students' discipline in public secondary schools in Monduli District.

\section{Methodology}

The study employed a quantitative approach under which cross sectional survey design was used. The design helped the researcher to collect data from the study participants at one time. The target population for the study consisted of the District Education Officer, 12 heads of schools, 406 teachers and 9,565 students in secondary schools in Monduli District. Simple random and stratified sampling techniques were used to select the students while the heads of sampled schools, teacher counselors together with the District Education Officer were directly involved in the study. Therefore, the study sample consisted of 1 District Education Officer, 6 heads of schools, 6 guidance and counseling teachers and 336 students making a total number of 349 respondents.

The study employed questionnaire and interview schedule to collect data from the participants. Questionnaires were used to collect data from heads of school, teacher counselors and students. This instrument was used due to its ability in collecting information from a large sample of respondents within a short period. It will also be good since it reduces biasness from the researcher's side because responses will be given in a written format. These questionnaires were tried out in one school to determine whether they give the required information before the actual data collection. The interview schedule was used to get information from the District Education Officer. The study was used this type of interview due to the position of the leader and its aim is, for the researcher to get first-hand information from respondent.

Data from the pilot study were used to estimate the reliability of the instruments. Reliability enabled the researcher to identify the doubts and inadequate items in the research instrument; where the instrument reliability is the dependability, consistency or trustworthiness of a test. Reliability is the consistency of the results from the measuring instruments whereby Cronbach's Alpha method was used to calculate reliability with the aid of Statistical Package for Social Sciences (SPSS) program version 20. The calculated reliability coefficients for teachers, heads of schools and students' questionnaires were $0.72,0.76$ and 0.81 respectively. According to Krathwohl (2009), the reliability coefficient of above 0.7 is considered to represent acceptable reliability. In determining the validity, before data collection the tools were given to two experts in research at Mwenge Catholic University. These experts assessed the relevance of the questions, language clarity and give suggestions for improvement. Their suggestions were then incorporated before the data collection process.

The researcher then sought permission from relevant offices for her to collect data. Upon being permitted, she visited the sampled schools and selected the students. Then, she distributed the questionnaires for the sampled students and teacher counselor as well as the head of schools. The questionnaires were filled on the same day and the researcher collected them for analysis. Then the researcher visited the District Education Officer for interview. The interview was conducted for thirty minutes. The collected data were then analyzed descriptively and inferentially. Descriptive analysis involved generating mean scores, and percentages while inferential statistics involved the testing of hypothesis whereby an independent sample t-test was used at 95\% confidence level. The researcher also adhered to the ethical principles in research including informed consent, voluntary participation, confidentiality and anonymity. 


\section{Findings}

\subsection{Perception of Students on the Provision of Guidance and Counseling Services in Secondary Schools in Monduli District}

The first research question aimed at finding out the perceptions of students on provision of guidance and counseling services in secondary school in Monduli District. To answer this question students and teachers were requested to indicate whether they agree or disagree on the statement provided in the questionnaire. Table 1 summarizes responses from students.

\begin{tabular}{|c|c|c|c|c|c|c|c|c|c|c|c|}
\hline \multirow[t]{2}{*}{ Statement } & \multicolumn{2}{|c|}{ SD } & \multicolumn{2}{|c|}{ D } & \multicolumn{2}{|c|}{$\mathbf{U}$} & \multicolumn{2}{|c|}{ A } & \multicolumn{2}{|c|}{ SA } & \multirow{2}{*}{$\begin{array}{c}\text { Mean } \\
\text { (M) }\end{array}$} \\
\hline & f & $\%$ & f & $\%$ & f & $\%$ & f & $\%$ & f & $\%$ & \\
\hline $\begin{array}{l}\text { i. Our guidance and } \\
\text { counseling services } \\
\text { teacher is very } \\
\text { friendly. }\end{array}$ & 0 & 0.0 & 0 & 0.0 & 63 & 19.0 & 132 & 39.9 & 136 & 41.1 & 4.17 \\
\hline $\begin{array}{l}\text { ii. I normally go to our } \\
\text { guidance and } \\
\text { counseling services } \\
\text { teacher when I have } \\
\text { problems. }\end{array}$ & 30 & 9.1 & 29 & 8.8 & 33 & 10.0 & 33 & 10.0 & 206 & 62.2 & 3.62 \\
\hline $\begin{array}{l}\text { iii. Our guidance and } \\
\text { counseling services } \\
\text { teacher give good } \\
\text { advice on our career } \\
\text { choices. }\end{array}$ & 31 & 9.4 & 43 & 13.0 & 28 & 8.5 & 105 & 31.7 & 124 & 37.5 & 4.07 \\
\hline $\begin{array}{l}\text { iv. The school has } \\
\text { provided guidance } \\
\text { and counseling } \\
\text { services teacher a } \\
\text { good private office } \\
\text { which ensures } \\
\text { privacy. }\end{array}$ & 58 & 17.5 & 48 & 14.5 & 30 & 9.1 & 67 & 20.2 & 128 & 38.7 & 3.99 \\
\hline $\begin{array}{l}\text { v. There is a special } \\
\text { day for guidance } \\
\text { and counseling } \\
\text { services only. }\end{array}$ & 27 & 8.2 & 97 & 29.3 & 33 & 10.0 & 94 & 28.4 & 80 & 24.2 & 3.74 \\
\hline $\begin{array}{l}\text { vi. The office of } \\
\text { guidance and } \\
\text { counseling services } \\
\text { is not important to } \\
\text { me. }\end{array}$ & 34 & 10.3 & 30 & 9.1 & 63 & 19.0 & 65 & 19.6 & 139 & 42.0 & 3.86 \\
\hline $\begin{array}{l}\text { vii. The time of offering } \\
\text { guidance and } \\
\text { counseling services } \\
\text { is not displayed in } \\
\text { the school time } \\
\text { table. }\end{array}$ & 33 & 10.0 & 34 & 10.3 & 64 & 19.3 & 98 & 29.6 & 102 & 30.8 & 4.16 \\
\hline $\begin{array}{lr}\text { viii. Guidance } & \text { and } \\
\text { counseling } & \text { services } \\
\text { are not only better } \\
\text { provided r by } \\
\text { competent teacher } \\
\text { counselors but also } \\
\text { by other teachers. }\end{array}$ & 30 & 9.1 & 60 & 18.1 & 28 & 8.5 & 98 & 29.6 & 115 & 34.7 & 4.20 \\
\hline Average mean score & & & & & & & & & & & 3.97 \\
\hline
\end{tabular}

Table 1: Students Views on the Provision of Guidance and Counseling Services in

Secondary Schools in Monduli District

Source;Field Data (2021)

Key:SD = Strongly Disagree, $D=$ Disagree, $U=$ Undecided, $A=$ Agree $S A=$ Strongly Agree

Data in Table 1 represents the views of students on the provision of guidance and counseling services in secondary schools. The findings shows that, the most of students have positive perceptions toward provision of guidance and counseling services at secondary schools by $\mathrm{M}=3.97$.The findings indicates that guidance and counseling services teachers have good social communication with students because most of students who participated in this study agreed 
that their guidance and counseling services teachers are so friendly that makes students feel free to visit the teacher counselor whenever they have problems and thus makes guidance and counseling services to be effective at school as supported by Egbo (2015).

Data in Table 1 shows that $72.2 \%$ of students agreed on statement "I normally go to our guidance and counseling services teacher when I have problems." while $17.9 \%$ of student disagreed. This implies that majority of students agreed that they normally go to their guidance and counseling teacher when they have problems. Findings indicates that students have good perceptions on guidance and counseling services provided at school because most of students who participated in this study agreed that they always visit teacher counselor whenever they have problems. Also, the findings indicates that there was good environment for guidance and counseling services created at school that makes students feel free to visit teacher counselor office whenever they have problems. These findings were supported by Eskicumali, (2016) who found out those students with problems benefit a lot from guidanceandcounseling services teachers.

The findings from the Table 1 indicates that $69.2 \%$ of students agreed to the fact that our guidance and counseling services teacher give good advice on their career choices while $22.4 \%$ of students disagreed that teacher counselors are not giving advice to students' choice of career. However, $8.5 \%$ of students are undecided on the fact that teacher counselor gives good advice to students' career choices. This means that most of students fixed that guidance and counseling provided by the teachers have created significant impact on their career choices. Students agreed that teachers play a great role here. This concurs with a study by Nkuba\&Kyaruzi (2015).

Also, data in Table 1 shows that $64.3 \%$ of students agreed on statement "Guidance and counseling services are not only better provided by competent teacher's counselors but also by other teachers." While $28 \%$ of students disagreed and $8.5 \%$ of students had no opinion. This implies that most of students agreed that guidance and counseling services are not only provided by competent teachers in counseling but also by other teachers too. This indicates that the issues of guidance and counseling services are for all teachers as they have common goal of students' academic excellence. From the findings teachers seem to understand student's academic excellence to be a collective activity. Furthermore, teachers understand problems facing students as they stay with them for much longer time than their parents do. Moreover, the school counselor, needs assistance from other teachers in order to improve students' discipline and academic performance as supported by Hearne \& Galvin, (2015) who argued guidance and counseling services involves all school stakeholders, including regular teachers' skills.

The researcher was also interested in establishing how teachers perceived guidance and counseling services in secondary schools in Monduli District. The responses are summarized in Table 2.

\begin{tabular}{|c|c|c|c|c|c|c|c|c|c|c|c|}
\hline \multirow[t]{2}{*}{ Statement } & \multicolumn{2}{|c|}{ SD } & \multicolumn{2}{|c|}{ D } & \multicolumn{2}{|r|}{$\mathbf{U}$} & \multicolumn{2}{|r|}{ A } & \multicolumn{2}{|c|}{ SA } & \multirow{2}{*}{$\frac{\text { Mean }}{\text { (M) }}$} \\
\hline & f & $\%$ & f & $\%$ & f & $\%$ & $f$ & $\%$ & $f$ & $\%$ & \\
\hline $\begin{array}{l}\text { i. Guidance and counseling services } \\
\text { have been helping students to } \\
\text { achieve goals in their academic } \\
\text { life. }\end{array}$ & 0 & 0 & 0 & 0 & 1 & 16.67 & 4 & 66.67 & 1 & 16.67 & 4.00 \\
\hline $\begin{array}{l}\text { ii. Guidance and counseling services } \\
\text { on time management has been } \\
\text { helping students to adjust time } \\
\text { management. }\end{array}$ & 0 & 0 & 0 & 0 & 2 & 33.33 & 4 & 66.67 & 0 & 0.00 & 3.67 \\
\hline $\begin{array}{l}\text { iii. Most of the students do not take } \\
\text { guidance and counseling services } \\
\text { seriously. }\end{array}$ & 1 & 16.7 & 0 & 0 & 1 & 16.67 & 3 & 50.00 & 1 & 16.67 & 3.50 \\
\hline $\begin{array}{l}\text { iv. Through guidance and counseling } \\
\text { services, students fear teachers } \\
\text { who know their personal life. }\end{array}$ & 1 & 16.7 & 3 & 50 & 1 & 16.67 & 1 & 16.67 & 0 & 0.00 & 2.33 \\
\hline $\begin{array}{l}\text { v. Guidance and counseling services } \\
\text { help students to improve their } \\
\text { academics. }\end{array}$ & 0 & 0 & 0 & 0 & 2 & 33.33 & 2 & 33.33 & 2 & 33.33 & 4.00 \\
\hline $\begin{array}{l}\text { vi. Guidance and counseling services } \\
\text { help students to achieve their } \\
\text { academic potential. }\end{array}$ & 0 & 0 & 0 & 0 & 1 & 16.67 & 3 & 50.00 & 2 & 33.33 & 4.17 \\
\hline $\begin{array}{l}\text { vii. Guidance and counseling services } \\
\text { help students to solve their } \\
\text { disciplinary issues. }\end{array}$ & 0 & 0 & 0 & 0 & 1 & 16.67 & 3 & 50.00 & 2 & 33.33 & 4.17 \\
\hline $\begin{array}{l}\text { viii. The presence of special room for } \\
\text { guidance and counseling services } \\
\text { ensures students' privacy }\end{array}$ & 1 & 16.7 & 0 & 0 & 1 & 16.67 & 2 & 33.33 & 2 & 33.33 & 3.67 \\
\hline Average mean score & & & & & & & & & & & 3.19 \\
\hline
\end{tabular}

Table 2: Teachers Responses on Perception of Students on the Provision of Guidance and Counseling Services in Secondary Schools in Monduli District

Key:SD = Strongly Disagree, $D=$ Disagree, $U=$ Undecided, $A=$ Agree $S A=$ Strongly Agree 
Data in Table 2 represents views of teachers on the perceptions of students on provision of guidance and counseling services in secondary schools in Monduli District. The findings shows that most of teachers indicated students to have positive perceptions towards provision of guidance and counseling services in secondary schools by M=3.19. Data from Table 1 shows that (83.33\%) of teachers agreed on statement "Guidance and counseling services have been helping students to achieve goals in their academic life" This implies that majority of teachers (83.33\%) who participated in this study agree that guidance and counseling services have been helping students to achieve goals in their academic life. From the findings, teachers confirmed that guidance and counseling services helps students to achieve goals in academic life. Supported by Nkechi et al. (2016) who found out that it is necessary for counselor to build confidence of the child to trust him or her to be able to give him or her rightful information needed in helping the child academic achievements.

Data in Table 2 also shows that $(66.67 \%)$ of teachers who participated in this study agreed on statement "Guidance and counseling services on time management has been helping students to adjust time management" while $(33.33 \%)$ of teachers' undecided. This implies that majority of teachers (66.67\%) agreed guidance and counseling services in time management has been helping students to manage time. The finding indicates that students are very well guided and counseled in time management. It is very important for students to understand how to manage times that make them to work smarter in their studies for better achievement in less time.

Also, findings in Table 2shows that (83.33\%) of teachers agreed on statement "Guidance and counseling services helps students to solve their disciplinary issues". The findings from students and teachers established that, students have good perception on guidance and counseling services provided. That indicates that, each school have guidance and counseling services with great impact in improving students' discipline and academic performance. This is in contrast to Arfasa, (2018). Generally, majority of students have positive perceptions towards provision of guidance and counseling services at school. This makes students to voluntary seek for guidance and counseling services when they have problems.

\section{Hypothesis Testing}

The following hypothesis as a null hypothesis was tested;

$\mathrm{H}_{\mathrm{o}}$ : There is no significant relationship between in the mean perceptions of teachers and students on the effectiveness of guidance and counseling services towards managing students' discipline in secondary schools in Monduli District. The researcher sought to look the relationship on the perceptions of teachers and students by comparing the effectiveness of guidance and counseling services towards managing students' discipline using $\mathrm{t}$ - Test.

\section{Assumptions of $\mathrm{t}$ - Test}

The samples are independent

Individual in each group is randomly and independently sampled

Only two levels are tested

\section{Decision Rule}

In either case; if the $P$-value is less than 0.05 , implies nominal level for statistical significance and it can be concluded that there is evidence of a statistically significant relationship or difference between two variables. The results of hypothesis testing are summarized in Table 5 .

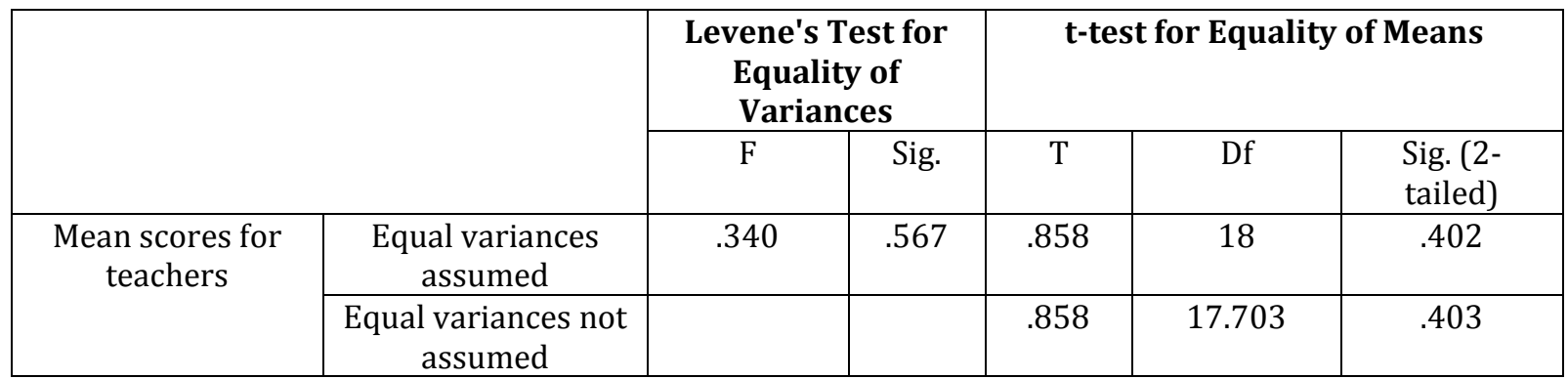

Table 3: Results of Hypothesis Testing

Source; Field Data (2021)

Results of statistical analysis shows that $\mathrm{t}(18)=0.858, \mathrm{p}-$ value $=0.402$. Since the $\mathrm{p}-$ value $(0.402)$ was greater than the significance level (0.05); the null hypothesis was not rejected. This means that there is no significant difference in the mean score perceptions of teachers and students on the effectiveness of guidance and counseling services towards managing students' discipline. Therefore, both teachers and students consider guidance and counseling services to be equally effective on managing students' discipline. Despite the challenges, the District Education Officer together with the teachers upheld that if well implemented guidance and counseling can effectively be used to maintain students' discipline.

\section{Conclusion}

Secondary school students in Monduli District have positive perceptions on the use of guidance and counseling services in the schools. Most of them do attend the guidance and counseling services when they are confronted with problems. They also enjoy the provided services as the teacher counselors are friendly and do listen to them. The teacher counselors also acknowledged to be receiving a good number of students who seek for assistance. Having positive 
perceptions signifies that guidance and counseling services offered in secondary schools in Monduli District are perceived by the students to be of significant importance towards managing their discipline.

\section{Recommendation}

Students should be provided with education concerning, attending guidance and counseling services. Though the study found out most of the students to perceive the provided services positively, still there are few who do not see the need of attending the services. They should be provided with education which will make them to change their perceptions and start attending the services. One of the ways of making the students to change their perceptions is to improve the quality of guidance and counseling services.

The Ministry of Education should ensure the availability of professional counselors in the schools who can effectively provide guidance and counseling services.

\subsection{References}

i. Agenda and W. Simatwa (2011). Management of Student Discipline in Secondary School. Unpublished Thesis, Maseno University.

ii. Agenda and W. Simatwa (2017). Management of Student Discipline in Secondary School. Unpublished Thesis, Maseno University.

iii. Arfasa, A. J. (2018). Perceptions of Students and Teachers toward Guidance and Counseling Services in South West Ethiopia Secondary Schools. International Journal of Multicultural and Multireligious Understanding, 5(6), 81-92.

iv. Chin, H. B., Sipe, T. A., Elder, R., Mercer, S. L., Chattopadhyay, S. K., Jacob, V., Wethington, H. R., Kirby, D., Elliston, D. B., Griffith, M., Chuke, S. O., Briss, S. C., Ericksen, I., Galbraith, J. S., Herbst, J. H., Johnson, R. L., Kraft, J. M., Noar, S. M., Romero, L. M., (2012). The effectiveness of group-based comprehensive risk-reduction and abstinence education interventions to prevent or reduce the risk of adolescent pregnancy, human immunodeficiency virus, and sexually transmitted infections: Two systematic reviews for the Guide to Community Preventive Services. American Journal of Preventive Medicine, 42(3), 272-294. https://doi.org/10.1016/j.amepre.2011.11.006

v. Egbo, A. C. (2015). The Challenges of Guidance and Counselling Practices as perceived by Secondary School Counsellors in Enugu State Nigeria. International Journal of Education and Research, 3(5), 375-384.

vi. Hearne, L., \& Galvin, J. (2015). The role of the regular teacher in a whole school approach to guidance counselling in Ireland. British Journal of Guidance \&Counselling, 43(2), 229-240.

https://doi.org/10.1080/03069885.2014.952622

vii. Hearne, L., \& Galvin, J. (2015). The role of the regular teacher in a whole school approach to guidance counseling in Ireland. British Journal of Guidance \& Counseling, 43(2), 229-240.

viii. Hughes, D., Law, B., \&Meijers, F. (2017). New school for the old school: Career guidance and counseling in education.

ix. Kambuga, Y., Manyengo, P., \&Mbalamula, Y. (2018). Corporal Punishment as a Strategic Reprimand used by Teachers to curb Students' Misbehaviours in Secondary Schools: Tanzanian Case. International Journal of Education and Research, 6(4), 183-194.

x. Karcher, M. J. (2004). Connectedness and school violence: A framework for developmental interventions. In E. Gerler (Ed.), Handbook of school violence (pp. 7-42). Binghamton, NY: Haworth Press.

xi. Kiptala, W., \&Kipruto, J. (2021). Students' Perception of the Influence of Guidance and Counselling Services and Academic Performance in Baringo Country, Kenya.EuropeanJournal of Education and Pedagogy, 2(1), 3235.https://doi.org/10.24018/ejedu.2021.2.1.12

xii. Kiragu, T. W. (2014). An Investigation of The Extent of Guidance and CounsellingProgrammes in Some Secondary Schools of Thika district, Kenya. (MEd Thesis). Kenyatta University, Nairobi. Retrieved from http://irlibrary.ku.ac.ke/handle/123456789/11781

xiii. Krathwohl, D. R. (2009). Methods of educational and social science research: The logic of methods. Waveland Press

xiv. Leahy, E., O'Flaherty, J., \& Hearne, L. (2017). The 'tyranny of time': Getting to the heart of the impact of educational cuts on the provision of guidance counselling in Ireland. British Journal of Guidance \&Counselling, 45(1), 97-111.

xv. Malisa, S.E. (2017). Effectiveness of counseling techniques in improving students' behaviour.

xvi. Mapfumo and Nkoma-2013-Freshmen Guidance and counselling received in hig.pdf. (n.d.). Retrieved November 2, 2021, from http://www.ijsrp.org/research-paper-1213/ijsrp-p2475.pdf

xvii. Meyer T.M (1991). The Dynamics of Human Communication: A laboratory Approach 6thEdition.Singapore:

xviii. Musa, M., \& Martha, A. A. (2020). School Management Mechanisms and Control of Discipline among Pupils in Primary Schools: An Analysis of Discipline in Upper Primary Level. Anatolian Journal of Education, 5(1), 1-16.

xix. Mutie, E. K \&Ndambuki, P.W. (1999). Guidance and counselling in Schools and Colleges. Nairobi: Oxford University Press.

xx. Ngalya, E. J. (2017). Management of Students' Indiscipline Cases in Public Secondary Schools in Temeke Municipality [Unpublished]. Open University of Tanzania.

xxi. Nkechi, E. E., Ewomaoghene, E. E., \&Egenti, N. (2016). The role of guidance and counselling in effective teaching and learning in schools. RAY: International Journal of Multidisciplinary Studies, 1(2), 36-48.

xxii. Nkuba, M., \&Kyaruzi, E. (2015). Is It Not Now? School Counselors' Training in Tanzania Secondary Schools. Journal of Education and Practice, 6(19), 160-169.

xxiii. Onyango, P. A., Aloka, P. J., \&Raburu, P. A. (2018). Effectiveness of guidance and counseling in the management of student behaveiour in public secondary schools in Kenya. Journal of Education and Practice, 7(13), 142-151. 
xxiv. Rue W and Byarr L (1992). Management Skills and Application. Boston: Arwin.

xxv. Salgong, V. K., Ngumi, D. O., \&Chege, D. K. (2016). The Role of Guidance and Counseling in Enhancing Student Discipline in Secondary Schools in Koibatek District. Journal of Education and Practice, 7(13), 10.

xxvi. Sima, R.G. (2018). The Challenges in the Provision of Counselling Services in Secondary Schools in Tanzania. Department of Educational Psychology and Curriculum Studies. University of Dar es Salaam.

xxvii. Stephens, P. A., Buskirk, S. W., Hayward, G. D., \& Martinez Del Rio, C. (2005). Information theory and hypothesis testing: A call for pluralism. Journal of Applied Ecology, 42(1), 4-12.

xxviii. URT, (2016). National Basic Education Statistics in Tanzania (BEST) 2012-2016 National Data. Dar es Salaam, Tanzania. 